\title{
Elimination diets - necessity or individual choice?
}

\author{
Martyna Rekowska ${ }^{1}$, Mieczysława Czerwionka-Szaflarska² \\ 'Department of Nutrition and Dietetics, Ludwik Rydygier Collegium Medicum in Bydgoszcz, \\ Nicolaus Copernicus University in Torun, Bydgoszcz, Poland \\ ${ }^{2}$ College of Medical Sciences, University of Economy, Bydgoszcz, Poland
}

\section{ABSTRACT}

Elimination diets are a standard of nutritional treatment in allergies, food intolerances, and congenital metabolic defects. The use of a long-lasting, restrictive elimination diet poses a risk of malnutrition and deficiencies of individual nutrients. In recent years, however, there has been an increase in their popularity among healthy people, including parents using various eliminations of food in their children. Incorrect nutrition, especially in infancy and early childhood, can have serious health consequences in subsequent life stages. A long-term elimination diet requires monitoring of its composition and the patient's nutritional status, as well as assessment of their development and growth. Also, additional supplementation may be necessary.

\section{KEY WORDS:}

gluten-free diet, elimination diet, vegetarianism, veganism, nutritional deficiencies.

\section{INTRODUCTION}

According to the definition, an elimination diet consists of the temporary or permanent elimination of a harmful or poorly tolerated food with simultaneous introduction of a substitute with equivalent nutritional value [1]. Elimination diets are the standard in nutritional treatment in the case of allergies, food intolerance, intolerance to food additives, as well as congenital metabolic disorders. The objective criteria of the efficacy of these diets should be the resolution or alleviation of symptoms, and in case of the children also the provision of proper physical and psychomotor development. Recently, elimination diets have gained significant popularity among healthy individuals.

The present paper attempts to systematise the current knowledge concerning this phenomenon on the examples of the following diets: low phenylalanine diet, gluten-free diet, and vegetarian diet, and to emphasise the difference between the necessity for the elimination diet in the therapy and the individual choice of the patient.

\section{THE NECESSITY}

\section{LOW PHENYLALANINE DIET}

A low phenylalanine diet is the gold standard in the therapy of the classic form of phenylketonuria (PKU), a congenital, genetically conditioned metabolic disease caused by lack of or significant decrease in the activity of phenylalanine hydroxylase (PAH). Due to the enzymatic deficiency, patients experience abnormalities in the transformation of phenylalanine amino acid to tyrosine, which leads to high phenylalanine levels in blood and consequently to damage of the central nervous system, and to developmental disorders [2].

A low phenylalanine diet is based on the reduction of the phenylalanine supply from natural protein products, with a concomitant increase in the total protein intake, mainly by the introduction of special low-phenylalanine or phenylalanine-free protein substitutes. These preparations are mixtures of synthetic amino acids supplemented with tyrosine (the amino acid that is deficient in the case

\section{ADDRESS FOR CORRESPONDENCE:}

Martyna Rekowska, Department of Nutrition and Dietetics, Ludwik Rydygier Collegium Medicum in Bydgoszcz,

Nicolaus Copernicus University in Torun, 3 Dębowa St., 85-626, Poland, e-mail: martyna.rekowska@wp.pl 
of the phenylketonuria), fat, carbohydrates, vitamins, and minerals. The phenylalanine supply, which can be sustained with food in the case of an individual with PKU, depends on conditions such as: age, body mass, physiological condition, and individual phenylalanine tolerance, i.e. such an amount of the amino acid supplied with a diet resulting in its safe level in patient's blood [3]. The recommended phenylalanine supply depending on the patient's age is presented in Table 1. The supply is defined empirically based on the concentration of this amino acid in the patient's blood serum. The reference values are given below: $2-6 \mathrm{mg} \%$ in children up to age 12 years and 2-10 $\mathrm{mg} \%$ in older children and adults. However, the optimum values regardless of age are up to $6 \mathrm{mg} \%$ [4].

In practice, the patients must eliminate the high-protein food with high phenylalanine content from the diet, i.a. meat, fish, milk and dairy products, eggs, cereals products, legumes, seeds, nuts, or gelatine. Food products with low phenylalanine content are allowed in precisely defined amounts, while phenylalanine-free food is not subjected to dietary restriction. Compliance with a low phenylalanine diet since the neonatal period, optimally throughout the entire life of the patient, is necessary during nutritional treatment. Early diagnosis and introduction of the appropriate treatment enable proper mental development of a child and prevent adverse neurological effects of the disease.

Phenylketonuria is diagnosed based on obligatory neonatal screenings using a colourimetric method or tandem mass spectrometry (MS/MS). The screening test performed in the third or fourth day of life is based on obtaining a blood sample from the child's heel on special tissue paper, and subsequently the phenylalanine concentration is determined. The incidence of the phenylketonuria in Poland, similarly to other Central European countries, is $1: 7000$ to $1: 8000$ live births; in the international literature it varies from $1: 2600$ to $1: 120,000$ live births $[5,6]$.

\section{GLUTEN-FREE DIET}

A gluten-free diet is based on the elimination of cereal products containing prolamins (conventionally known as gluten), i.e. wheat and triticale gliadins, rye secalin, barley hordein, and oat avenin, from the diet. Efforts are focused on selecting special food products made of grains that naturally do not contain gluten (e.g. rice, corn, millet, buckwheat, sorghum, tapioca, amaranth) and which are not contaminated with this protein during the manufacturing process, as well as other naturally gluten-free products, and gluten-containing cereals with gluten removed in the technological process. So-called gluten-free foods are products with a total gluten content below $20 \mathrm{mg} / \mathrm{kg}$ ( $<20 \mathrm{ppm}$ ).

According to current knowledge, the classification of gluten-related diseases includes: coeliac disease, allergy to wheat, and non-coeliac gluten sensitivity (NCGS).
TABLE 1. The recommended intake of phenylalanine depending on the age of the patient [4]

\begin{tabular}{|l|c|}
\hline Group of patients & $\begin{array}{c}\text { Intake of phenylalanine with } \\
\text { diet ( } \mathrm{mg} / \mathrm{kg} / \mathrm{day})\end{array}$ \\
\hline Newborns and infants & $30-80$ \\
\hline $\begin{array}{l}\text { Toddlers and pre-school } \\
\text { children }\end{array}$ & $20-40$ \\
\hline School-age children & $10-20$ \\
\hline Adults & 10 \\
\hline
\end{tabular}

Coeliac disease (CD), defined as persistent gluten intolerance, is an autoimmune disorder that can occur in genetically predisposed people, where the ingestion of gluten causes a chronic inflammatory process leading to damage in the small intestine and villous atrophy. The incidence of coeliac disease in the general population is about $1 \%$ [7]. The relation of the patients with CD to currently undiagnosed patients is estimated to be just $1: 5$ to $1: 10$, and individuals diagnosed with $\mathrm{CD}$ are thought to be just the "tip of the iceberg" of all actual cases [8]. According to ESPGHAN criteria, diagnostic work-up of coeliac disease is based on serological tests, genetic tests, and small intestine biopsies. Three types of antibodies are useful in serological tests: against tissue transglutaminase (tTG), against deamidated gliadin peptides (DGP), and against the intestinal tract smooth muscles endomysium (EmA) [9]. Blood serum is the material used for testing. Genetic tests, which are currently more available and widely used, can determine the presence of the HLA DQ2 or HLA DQ8 haplotypes. The negative result of the test in the case of a person with suspected coeliac disease excludes it with a high probability. However, confirmation of the presence of these molecules cannot be the basis of the disease diagnosis and provides only a genetic predisposition to CD. Today it is known that DQ2 or DQ8 is observed in about $30 \%$ of the general population. In the same time, only $3-4 \%$ of the individuals from this group suffer, or will suffer in future, from coeliac disease [10]. In most of the cases, the confirmation of CD still requires the results of a small intestine biopsy with histopathological assessment of the samplings according to Marsh classification [9].

In case of the patients diagnosed with coeliac disease, a gluten-free diet is the treatment of choice for their whole life. Strict elimination of gluten from the diet in most cases leads to the regeneration of the mucous membrane of the small intestine, resolution of the clinical symptoms of the disease, and improvement in the laboratory parameters and nutritional status.

The incidence of gluten-dependent allergic diseases is estimated at $1 \%$, in which most of the patients are diagnosed with an allergy to wheat proteins that requires a diet eliminating only wheat [11]. The under- 
lying of allergy to wheat may have both IgE-mediated and non-IgE-mediated mechanisms. The clinical picture depends on age: gastroenterological symptoms prevail in infants and young children, while older children suffer mostly from dermatitis, respiratory disorders, and, in severe cases, anaphylaxis [11]. Diagnostics are based mainly on the medical history, determination of specific IgE antibody concentrations in serum, and skin prick tests (SPT), but a double-blind, placebo-controlled food challenge (DBPCFC) with wheat remains the basis for the diagnosis $[11,12]$. In IgE-mediated wheat allergy, in half of the patients, tolerance develops up to the age of 8 years and in $2 / 3$ of the patients up to 12 years [13].

Non-coeliac gluten sensitivity (NCGS) is a new disease characterised by the presence of gastrointestinal symptoms (abdominal pain, diarrhoea, constipation) as well as symptoms outside the gastrointestinal tract (tiredness, headache, muscle pain, arthralgia). It occurs after ingestion of gluten in people who do not meet the criteria for a diagnosis of coeliac disease or allergy to wheat.

The literature shows that patients with NCGS can represent the most prominent group requiring the elimination of gluten from the diet. In estimations, this group can include $6 \%$ of the population [14]. However, it should be noted that it is a relatively new disease entity, diagnosed for a short time, and currently there is a lack of reliable epidemiological data from most countries. The cause and effect relationship between gluten intake and the occurrence of clinical symptoms in NCGS should be confirmed by a double-blind, placebo-controlled food challenge [15, 16]. According to Biesiekierski et al. [17], only every fourth person who declares self-diagnosis with non-coeliac gluten sensitivity meets the real diagnostic criteria for this illness.

In patients with confirmed NCGS, a gluten-free diet is used in treatment, but it is not known whether it is safe to eat small amounts of gluten or it is necessary to follow a strict gluten-free diet, as in patients with coeliac disease. According to the current state of knowledge, the required precise duration of a gluten-free diet in the case of non-coeliac gluten sensitivity is also unknown.

\section{AN INDIVIDUAL CHOICE - THE TREND}

\section{GLUTEN-FREE DIET}

The application spectrum of the wheat grain, the most popular gluten-containing cereal in human nutrition, is highly extensive. Wheat crops are widespread in all continents; however, the highest consumption is reported in Europe and North America. Even though the position of wheat and rye as primary bread cereals seems to be stable, in recent years the gluten-free diet has started to become more and more popular among healthy individuals. It used to be an unpleasant necessity and the only treatment for coeliac disease patients, but today it has become pop- ular and is often favoured with no medical justification. The scale of the phenomenon is increasing, and currently in Australia estimates show that for one person diagnosed with coeliac disease there are 20 people without CD who consume specialist gluten-free products. In the USA almost every fifth person uses this type of food [18].

The results of a survey conducted with 1500 American adults on a gluten-free diet show that $35 \%$ of them did not give any specific reason for this choice, and $26 \%$ of the respondents considered the gluten-free diet simply as healthier in comparison with the traditional one. Only $8 \%$ of the respondents indicated that gluten intolerance is the reason for such a dietary intervention, and it was the least popular answer in the survey [19].

Despite the prevailing conviction that the elimination of gluten from the diet leads to many health benefits, present studies show that this type of diet can lead to an increase in caloric content - fat and monosaccharide content - and low dietary fibre intake, mainly due to selection of highly processed gluten-free products [20, 21]. Furthermore, the authors of the prospective cohort study from 2017 conducted on 100 thousand individuals over 26 years old did not show a relationship between long-term consumption of food containing gluten and increased risk of ischaemic heart disease [22]. Taking into account the studies mentioned above, the demonising of gluten seems to be not entirely justified, and there is no basis to suggest that a gluten-free diet for healthy individuals will reduce the risk associated with the occurrence of the cardiovascular diseases.

Some recent studies suggest a relationship between implementation of gluten-free and milk-free (casein-free) diet (GFCF) and the improvement concerning behaviour in some children with autism spectrum disorders [23, 24]. So-called opioid theory is used to explain this relationship, which suggests that the original reason for the autism disorders is the increased gastrointestinal permeability (leaky gut). According to this assumption, the patients experience free infiltration of incompletely digested peptides - gliadomorphine derived from gluten and casomorphin from cow's milk casein - through the intestine and subsequently through the blood-brain barrier. It is considered that due to the similar chemical structure these molecules can be similar in properties to the opiates and can act directly on the central nervous system leading to, among others, emotion perception abnormalities, loss of language skills, social withdrawal, perception disorders, and pain insensitivity.

Further, well-planned studies are required because the role of the elimination of the individual nutritions in autism spectrum disorders is still controversial. According to the current literature, the evidence of the benefits of a GFCF diet in patients with autism are insufficient [25-28]. The exceptions to this are patients diagnosed with an allergy or food intolerance. Rubenstein et al. [29] observed that every fifth studied child with autism 
TABLE 2. Types of vegetarianism

\begin{tabular}{|l|c|c|}
\hline Types of vegetarianism & Food allowed & Food not allowed \\
\hline Semi-vegetarianism & $\begin{array}{c}\text { meat, poultry and fish - in smaller quantities, eggs, milk } \\
\text { and dairy products, vegetables, fruits, cereals, seeds, nuts }\end{array}$ & \\
\hline $\begin{array}{l}\text { Lacto-ovo- } \\
\text { vegetarianism }\end{array}$ & $\begin{array}{r}\text { eggs, milk and dairy products, vegetables, fruits, } \\
\text { cereals, seeds, nuts }\end{array}$ & meat, poultry, fish \\
\hline $\begin{array}{l}\text { Lacto-vegetarianism } \\
\text { milk and dairy products, vegetables, fruits, cereals, } \\
\text { seeds, nuts }\end{array}$ & meat, poultry, fish, eggs \\
\hline Ovo-vegetarianism & eggs, vegetables, fruits, cereals, seeds, nuts & meat, poultry, fish, milk and dairy products \\
\hline Veganism & vegetables, fruits, cereals, seeds, nuts & meat, poultry, fish, milk and dairy products, eggs \\
\hline Fruitarianism & $\begin{array}{r}\text { fruits } \\
\text { meat, poultry, fish, eggs, milk and dairy pro- } \\
\text { ducts, vegetables, cereals, seeds, nuts }\end{array}$ \\
\hline Raw food veganism & $\begin{array}{r}\text { vegles, fruits, cereals, seeds, nuts - } \\
\text { in an unprocessed form }\end{array}$ & \begin{tabular}{c} 
meat, poultry, fish, milk and dairy products, eggs \\
\hline
\end{tabular} \\
\hline
\end{tabular}

in pre-school age was, at least temporarily, subjected to a gluten-free diet, and half of these interventions were the decision of parents without any consultation with a specialist.

There is no doubt that the rise in popularity of the gluten-free diet, also in Poland, has contributed to increased access to the various, specialist gluten-free foods for sick individuals; on the other hand, it has also caused the emergence of products with reduced gluten content, which are considered to be "healthier" - so-called low-gluten content products. In the consciousness of society, these products are often confused with gluten-free food. However, due to much higher gluten content (up to $100 \mathrm{mg} / \mathrm{kg}$ ), these products are not equivalent to gluten-free products and cannot be consumed by individuals suffering from gluten-dependent conditions.

According to the current state of knowledge, a properly balanced gluten-free diet is not perceived as unhealthy. However, the benefits of using a gluten-free diet, compared to a gluten-containing diet, are not clear in healthy individuals [30].

\section{VEGETARIAN DIET}

In recent years the popularity of vegetarianism - both as a diet as well as an element of life philosophy - seems to be increasing constantly. Estimates show that the vegetarian diet is already used by 1 million Poles [31]. In the USA almost $3.3 \%$ of adults are vegetarian, and almost half of these are vegan [32].

Vegetarianism has many variants, which differ significantly from each other concerning dietary restrictions. Vegetarian cuisine is based on products and meals that do not contain meat, including poultry, as well as fish and seafood. Lacto-vegetarians, besides vegetable products, also consume milk and dairy products, and lacto-ovo-vegetarians additionally consume eggs. A strict vegetarian diet, i.e. a vegan diet, allows consumption of plant products only. Macrobiotics are more radical, and their diet is based mainly on cereals, legumes, and vegetables, with fruits, nuts, and seeds used to a lesser extent. The most popular types of vegetarianism are presented in Table 2.

The reasons for the selection of the diet in case of vegetarians are, most commonly, health reasons, care for the environment, and health protection, as well as ethical and religious beliefs [33].

The American Dietetic Association published a statement in 2009 accepting a properly planned vegetarian diet, including a vegan diet, as safe for people in all stages of life, also during childhood. According to the authors, it can also be used as a prevention tool for the occurrence of civilisation diseases, such as arterial hypertension, obesity, type 2 diabetes, ischaemic heart disease, and some types of neoplasms. The vegetarian diets include less saturated fatty acids, cholesterol, and more dietary fibre, vitamin $\mathrm{C}$ and $\mathrm{E}$, carotenoids, folates, as wells as magnesium, potassium, and flavonoids, compared with a standard diet [33]. It is accepted that extremely radical forms of vegetarianism - fruitarianism, veganism, and macrobiotic diets - cause significant dietary deficiencies and growth inhibition in children, and thus are not recommended for nutritional purposes [33]. The same statement was published in 2016 after the change of the society name to the Academy of Nutrition and Dietetics [34].

However, the specialists have various opinions concerning this subject. As long as reasonable elimination of a food of animal origin in the diet of adult individuals does not cause any greater concern, the introduction of strictly plant diet in the paediatric population is still highly controversial. According to the National Consultant in Paediatrics in Poland, vegan and macrobiotic diets are not recommended during developmental age, and only a properly balanced lacto-ovo-vegetarian diet, thus containing milk, dairy products, and eggs, can be regarded as safe [35]. The Institute of Food and Nutrition stated in 
2012 that, besides the lacto-ovo-vegetarian diet, also the lacto-vegetarian diet is regarded as safe, provided that all nutrients required for a given age group are included [36]. The literature shows that the development of children and adolescents on lacto-ovo-vegetarian diet is similar to the development observed in case of the non-vegetarian peers $[37,38]$. It also seems that these individuals have better nutrition habits and eat more vegetables and fruits, and fewer sweets, salty snacks, and fast-foods in comparison with children on a standard diet $[39,40]$.

It should be noted that a vegetarian diet can be beneficial to health, but not in all cases. In the case of highly processed food, low variety of diet, and inappropriate selection of fat sources, the preparation of balanced meals is not possible. Appropriate balancing of the vegetarian diet is often difficult for parents, especially if a child is not under a dietician's care. The biological availability of plant origin proteins is $10-20 \%$ lower than in the case of animal proteins; thus, one should remember that the consumption of proteins in individuals on a vegetarian diet, and especially a vegan diet, should be correspondingly higher [41, 42]. Vegetarians are especially susceptible to deficiencies in vitamin $B_{12}$ (which is not present in plants), vitamin $\mathrm{D}_{3}$, and in the minerals: iron, zinc, calcium, and iodine, and omega-3 fats [33,34]. On the other hand, due to the lower bioavailability of iron in vegetarian diets (non-heme iron), the recommended consumption of these macronutrients in the case of vegetarians is 1.8-times higher than in the case of individuals on a standard diet $[33,43]$. The deficiencies presented above can be prevented by the selection of appropriate food products and application of the rules of healthy nutrition. The exception is vitamin $B_{12}$, which must be supplemented in the form of pharmaceutical preparations or fortified food. The diversity of the nutritional habits of vegetarians indicates a need to perform dietary assessment for each patient individually [33].

\section{RISKS ASSOCIATED WITH ELIMINATION DIETS}

The essence of the elimination diet is to replace the eliminated ingredient with a food of similar quality and quantity to protect the patients from the occurrence of nutritional deficiencies. It should be emphasised that a properly balanced elimination diet should offer the appropriate supply of energy and all nutrients. Dietary mistakes and long-term restriction diets can potentially be the cause of malnutrition and deficiency of individual nutrients, including proteins, vitamins, and minerals.

Low phenylalanine diet in patients with phenylketonuria, and thus permanent elimination of foods with high nutritional value, especially being an abundant source of proteins, vitamins, and minerals, can cause a risk of nutritional deficiencies. The literature shows that this group of patients is most commonly deficient in micro- and mac- ronutrients, including selenium, iron, zinc, and vitamins, especially $B_{12}$ [44-49].

Despite the fact that a qualitatively and quantitatively balanced gluten-free diet does not promote the occurrence of nutritional deficiencies, observations show that in the case of coeliac patients this diet is characterised by high fat content and higher energy density in comparison with a standard diet [20]. The literature also describes the relationship between a gluten-free diet and the development of overweight and obesity in coeliac patients $[21,50]$.

According to Valletta et al. [21], a significant influence on weight gain in this group of patients is caused by the change in lifestyle and nutritional choices after the introduction of a gluten-free diet, i.e. excessive consumption of the high-protein and high-fat, highly processed non-gluten food with a concomitant low supply of dietary fibre.

As stated above, vegetarians are especially susceptible to the deficiencies in vitamins $\mathrm{B}_{12}$ and $\mathrm{D}_{3}$, iron, zinc, calcium, iodine, and unsaturated fatty acids of the omega-3 family $[33,34]$. However, special attention should be paid to the statement of the Institute of Food and Nutrition [36], which shows that both standard and vegetarian diets, while unbalanced, can pose the risk of deficiencies in some nutrients, and consequently abnormal functioning of the organisms.

\section{CONCLUSIONS}

The diseases that require the introduction of elimination diets for medical purposes, such as allergies and food intolerances or metabolic defects, are today a significant medical and social problem. In view of the studies mentioned above, it seems to be necessary to emphasise that without a medical diagnosis, recommendations, and instructions given by an experienced dietician one should not make decisions concerning the introduction of radical elimination diets, especially in case of paediatric patients. Inappropriate diet, especially during infancy and early childhood, can lead to serious health consequences in subsequent stages of life.

A patient who excludes products from their diet should stay under constant medical and dietary care for the prevention of nutrition deficiencies. Implementation of unjustified and overly restrictive elimination diets should be avoided. Without doubt, long-term elimination diets require monitoring of their composition and the patients' nutrition status, assessment of development and growth, and often the introduction of additional supplementation.

\section{DISCLOSURE}

The authors declare no conflict of interest. 


\section{REFERENCES}

1. Kaczmarski M. Nadwrażliwość pokarmowa u dzieci i młodzieży. Stand Med Pediatr 2009; 3: 379-398.

2. van Wegberg AMJ, MacDonald A, Ahring K, et al. The complete European guidelines on phenylketonuria: diagnosis and treatment. Orphanet J Rare Dis 2017; 12: 162.

3. Żółkowska J. Postępowanie dietetyczne w klasycznej postaci fenyloketonurii. Stand Med Pediatr 2014; 11: 555-564.

4. Kałużny Ł. Pediatria Metaboliczna. In: Żywienie dzieci w zdrowiu i chorobie, Krawczyński M (ed.). Help-Med, Kraków 2015; 241-253.

5. Bożkowa K, Cabalska B, Radomyska B, et al. Ocena przydatności badań przesiewowych u noworodków w świetle 35 lat doświadczeń własnych. Medycyna Wieku Rozwojowego 1999; 3: 529-559.

6. Sendecka E, Cabalska B. Standardy rozpoznawania i leczenia fenyloketonurii. Med Wieku Rozw 2001; 5: 77-94.

7. Ludvigsson JF, Bai JC, Biagi F, et al. BSG Coeliac Disease Guidelines Development Group; British Society of Gastroenterology: Diagnosis and management of adult coeliac disease: guidelines from the British Society of Gastroenterology. Gut 2014; 63: 1210-1228.

8. Norström F, Lindholm L, Sandström O, et al. Delay to celiac disease diagnosis and its implications for health-related quality of life. BMC Gastroenterol. 2011; 11: 111-118.

9. Husby S, Koletzko S, Korponay-Szabó IR, et al. European Society for Pediatric Gastroenterology, Hepatology, and Nutrition guidelines for the diagnosis of coeliac disease. J Pediatr Gastroenterol Nutr 2012; 54: 136-60.

10. Megiorni F, Pizzuti A. HLA-DQA1 and HLA-DQB1 in Celiac disease predisposition: practical implications of the HLA molecular typing. J Biomed Sci 2012; 19: 88-92.

11. Czaja-Bulsa G, Bulsa M. What Do We Know Now about IgE-Mediated Wheat Allergy in Children? Nutrients 2017; 9: 35.

12. Cianferoni A. Wheat allergy: diagnosis and allergy: diagnosis and management. J Asthma Allergy 2016; 9: 13-25.

13. Czaja-Bulsa, G, Bulsa M. The natural history of IgE mediated wheat allergy in children with dominant gastrointestinal symptoms. Allergy Asthma Clin Immunol 2014; 10: 12.

14. Sapone A, Bai J, Ciacci C, et al. Spectrum of gluten disorders: consensus on New nomenclature and classification. BMC Medicine 2012; 10: 13 .

15. Catassi C. Gluten sensitivity. Ann Nutr Metab 2015; 67 (Suppl 2): $16-26$.

16. Catassi C, Elli L, Bonaz B, et al. Diagnosis of Non-Celiac Gluten Sensitivity (NCGS): The Salerno Experts' Criteria. Nutrients 2015; 7: 4966-4977.

17. Biesiekierski JR, Newnham ED, Shepherd SJ, et al. Characterization of Adults With a Self-Diagnosis of Nonceliac Gluten Sensitivity. Nutr Clin Pract 2014; 29: 504-509.

18. Hozyasz K. Nieceliakalna nadwrażliwość na gluten (NCNG). Celiakia. Dieta bezglutenowa. Wiedzieć więcej. Stowarzyszenie Przyjaciół Chorych na Celiakię „Przekreślony Kłos”, Bydgoszcz 2016; 43-56.

19. The Hartman Group: The Hartman Group's Health \& Wellness 2015 and Organic \& Natural 2014 reports. http://www.hartman-group. com/acumenPdfs/gluten-free-2015-09-03.pdf (access: 11.03.2018).

20. Reguła J, Śmidowicz A. Share of dietarysupplements in nutrition of coeliac disease patients. Acta Sci Pol Technol Aliment 2014; 13: 301-307.

21. Valletta E, Fornaro M, Cipolli M, et al. Celiac disease and obesity: Need for nutritional follow-up after diagnosis. Eur J Clin 2010; 64: 1371-1372.

22. Lebwohl B, Cao Y, Zong G, et al. Long term gluten consumption in adults without celiac disease and risk of coronary heart disease: prospective cohort study. BMJ 2017; 357: j1892.
23. El-Rashidy O, El-Baz F, El-Gendy Y, et al. Ketogenic diet versus gluten free casein free diet in autistic children: a case-control study. Metab Brain Dis 2017; 32: 1935-1941.

24. Ghalichi F, Ghaemmaghami J, Malek A, et al. Effect of gluten free diet on gastrointestinal and behavioral indices for children with autism spectrum disorders: a randomized clinical trial. World J Pediatr 2016; 12: 436-442.

25. Elder JH, Kreider CM, Schaefer NM, et al. A review of gluten- and casein-free diets for treatment of autism: 2005-2015. Nutr Diet Suppl 2015; 7: 87-101.

26. Lange KW, Hauser J, Reissmann A. Gluten-free and casein-free diets in the therapy of autism. Curr Opin Clin Nutr Metab Care 2015; 18: 572-575.

27. Piwowarczyk A, Horvath A, Łukasik J, et al. Gluten- and casein-free diet and autism spectrum disorders in children: a systematic review. Eur J Nutr 2018; 57: 433-440.

28. Sathe N, Andrews JC, McPheeters ML, et al. Nutritional and Dietary Interventions for Autism Spectrum Disorder: A Systematic Review. Pediatrics 2017; 139: pii: e20170346.

29. Rubenstein E, Schieve L, Bradley C, et al. The prevalence of gluten free diet use among preschool children with autism spectrum disorder. Autism Res 2018; 11: 185-193.

30. Szajewska H. Celiakia. Med Prakt 2017; 1: 110-112.

31. http://www.lightbox.pl/poradnik-lightbox/zdrowe-odzywianie/ wyniki-badania-instytutu-badania-opinii-homo-homini-dla-lightbox-wrzesien-2013 (access: 11.03.2018).

32. Stahler C. How often do Americans eat vegetarian meals? And how many adults in the US are vegetarian? The Vegetarian Resource Group website. http://www.vrg.org/nutshell/Polls/2016_adults_veg. htm (access: 11.03.2018).

33. Craig WJ, Mangels AR. American Dietetic Association: Position of the American Dietetic Association: vegetarian diets. J Am Diet Assoc 2009; 109: 1266-1282.

34. Melina V, Craig W, Levin S. Position of the Academy of Nutrition and Dietetics: Vegetarian Diets. J Acad Nutr Diet 2016; 116: 19701980.

35. Dobrzańska A, Czerwionka-Szaflarska M, Siwińska-Gołębiowska H, et al. Stanowisko Konsultanta Krajowego w dziedzinie Pediatrii i Zespołu Ekspertów w sprawie stosowania w wieku rozwojowym diet wegetariańskich. Stand Med Pediatr 2002; 4: 436-439.

36. Position of the Institute of Food and Nutrition. http://wegemaluch. pl/download/iziz_odpowiedz_na_petycje.pdf (access: 11.03.2018).

37. Hebbelinck M, Clarys P. Physical growth and development of vegetarian children and adolescents. In: Sabate J (ed.). Vegetarian $\mathrm{Nu}-$ trition. FL: CRC Press, Boca Raton 2001; 173-193.

38. Książyk J, Jakubowska-Winecka A, Świąder A, et al. Rozwój intelektualny i antropologiczna ocena stanu odżywienia dzieci na diecie wegetariańskiej. Stand Med Pediatr 2012; 9: 279-284.

39. Larsson CL, Johansson GK. Young Swedish vegans have different sources of nutrients than young omnivores. J Am Diet Assoc 2005; 105: 1438-1441.

40. Perry CL, McGuire MT, Neumark-Sztainer D, et al. Adolescent vegetarians. How well do their dietary patterns meet the Healthy People 2010 objectives? Arch Pediatr Adolesc Med 2002; 156: 431-437.

41. Mangels AR, Messina V. Considerations in planning vegan diets: infants. J Am Diet Assoc 2001; 101: 670-677.

42. FAO/WHO/UNU Expert Consultation on Protein and Amino Acid Requirements in Human Nutrition. Protein and Amino Acid Requirements in Human Nutrition: Report of a Joint FAO/WHO/ UNU Expert Consultation. Geneva, Switzerland: World Health Organization 2002. WHO Technical Report Series No. 935.

43. Institute of Medicine, Food and Nutrition Board. Dietary Reference Intakes for Vitamin A, Vitamin K, Arsenic, Boron, Chromium, Copper, Iodine, Iron, Manganese, Molybdenum, Nickel, Silicon, 
Vanadium, and Zinc. National Academies Press; Washington DC 2001. http://www.who.int/iris/handle/10665/43411

44. Feillet F, Agostini C. Nutritional issues in treating phenylketonuria. J Inherit Metabol Dis 2010; 33: 659-666.

45. Procházková D, Jarkovský J, Vinohradská H, et al. Controlled diet in phenylketonuria and hyperfenylalaninemia may cause serum selenium deficiency in adult patients: the Czech experience. Biol Trace Element Res 2013; 154: 178-184.

46. Procházková D, Jarkovský J, Haňková Z, et al. Long-term treatment for hyperphenylalaninemia and phenylketonuria: a risk for nutritional vitamin B12 deficiency? J Pediatr Endocrinol Metab 2015; 28: 1327-1332.

47. Robert M, Rocha JC, van Rijn M, et al. Micronutrient status in phenylketonuria. Mol Genet Metab 2013; 110 (Suppl): 6-17.

48. Vugteveen I, Hoeksma M, Bjorke-Monsen AL, et al. Serum vitamin B12 concentration within reference values do not exclude functional vitamin B12 deficiency in PKU patients of various ages. Mol Genet Metab 2011; 102: 13-17.

49. Walter JH. Vitamin B12 deficiency and phenylketonuria. Mol Genet Metab 2011; 104: 52-54.

50. Brambilla P, Picca M, Dilillo D, et al. Changes of body mass index in celiac children on a gluten-free diet. Nutr Metab Cardiovasc Dis 2013; 23: 177-182. 